\title{
Madurai Formula Films: Caste Pride and Politics in Tamil Cinema
}

Karthikeyan Damodaran and Hugo Gorringe

\section{OpenEdition}

\section{Journals}

Electronic version

URL: http://journals.openedition.org/samaj/4359

DOI: $10.4000 /$ samaj.4359

ISSN: 1960-6060

\section{Publisher}

Association pour la recherche sur l'Asie du Sud (ARAS)

\section{Electronic reference}

Karthikeyan Damodaran and Hugo Gorringe, « Madurai Formula Films: Caste Pride and Politics in Tamil Cinema », South Asia Multidisciplinary Academic Journal [Online], Free-Standing Articles, Online since 22 June 2017, connection on 23 April 2019. URL : http://journals.openedition.org/samaj/4359 ; DOI : 10.4000/samaj.4359

This text was automatically generated on 23 April 2019

\section{cc)}

This work is licensed under a Creative Commons Attribution-NonCommercial-NoDerivatives 4.0 International License. 


\title{
Madurai Formula Films: Caste Pride and Politics in Tamil Cinema
}

\author{
Karthikeyan Damodaran and Hugo Gorringe
}

Acknowledgements: We are immensely grateful to Stalin Rajangam for insightful comments and to the anonymous reviewers of the journal who helped to sharpen the argument. The authors are indebted to the University of Edinburgh and the ESRC respectively for funding the fieldwork that enabled the discussions and observations on which this paper draws.

\section{Introduction}

1 Addressing a public meeting, the wonderful Communist Party of India (Marxist) orator, N. Nanmaran MLA, once stated that when people in Chennai (formerly known as Madras; the state capital of Tamil Nadu, the southernmost state in India) came to know that he was from Madurai (city in central Tamilnadu) they would invariably-with a mix of curiosity and apprehension-ask; "Do people in Madurai always carry sickles behind their shirts?" This, he concluded, is what Tamil cinema's representation of Madurai has achieved. It is the films which have created this exaggerated stereotype, and their social consequences, that concern us here.

2 Tamil cinema has been amongst the most socially and politically significant industries in the state; films form an integral part of the social, cultural and political life of the people here perhaps more than in any other region in India. ${ }^{1}$ As Nandy (1998:16) insists, in his overview of Indian cinema:

Tamil cinema ... has had an altogether different relationship with politics. (Tamil

film-stars are popular not only by virtue of their cinematic appeal but also because

of the close links they maintain with political parties and the checkered political career of the Tamil film industry itself).

Tamil Nadu produces the most films in a year, its landscape is ornamented with cinema posters, cut-outs and fan clubs, and for almost half a century the state has been ruled by politicians who made their names and secured their popularity through their association with the tinsel world (Jacob 2009). All of this, of course, is well known and much has been 
written about the umbilical link between politics and cinema (Dickey 1993; Hardgrave 1973). There has been less analysis, however, of the impact of this medium on social relations in the state. ${ }^{2}$

3 Likewise, whilst volumes have been devoted to discussing the significance of caste in Tamil politics, there has been less attention paid to the ways in which caste is played out in the cultural sphere of film (but see Srinivas and Kaali 1998). This is particularly surprising given the social significance of the medium. Given that politicians have used films to launch and sustain their careers, embed themselves in the public consciousness and shift public discourse in subtle ways, there is a need for analysis of the implicit caste norms and values carried in these films and the impact that they have. In this paper we offer an analysis of films since 1985 to suggest that the representations of caste dominance popularized in these movies have served to reinforce a social common sensefollowing Gramsci (1971) and Pandian (1992)-in which the Thevar cluster of intermediate castes are understood as martial, violent, and socially dominant. Additionally, we argue that there is a symbiotic relationship between caste politics and cinema particularly through the naturalization of intermediate caste markers and narratives. This paper focuses on caste as a major element in popular films, and explores how images, screenplay, costumes, dialects and songs depict a certain normative form against which a deviant "other" is constructed.

Primarily drawing on secondary sources and a close reading of multiple films we argue that the films of this period largely carried thematic structures and visuals depicting and glorifying the intermediate castes. These so-called Backward Castes are increasingly influential in Tamil Nadu and their rise to power has coincided with the cinematic valorization of dominant castes. We support our analysis where appropriate with observations from ethnographic research carried out by both authors. ${ }^{3}$ Tamil caste politics is complex, yet our analysis depends upon a basic understanding of caste dynamics in the state. In what follows, therefore, we begin with an overview of the key caste clusters discussed in this paper. We move, then, to a brief review of the literature on Tamil cinema, and an analysis of the films before closing with a wider discussion.

\section{The Caste Backdrop to Tamil Cinema}

5 Firstly, it is important to note that there are no representatives of the Kshatriya category of warrior or kingly castes in Tamil Nadu (Washbrook 1976). Since the displacement of Brahmins, those who wield socio-economic power here are those categorized as Shudraor serving castes elsewhere. This fact has multiple implications for the study of caste politics. Firstly, it explains how political parties that sidelined the egalitarianism of the Dravida Kazhagam (Dravidian Federation) with regard to the Dalits, could still portray themselves as radical because they championed the interests of the Backward Classes. Secondly, the fact that dominant castes are just above Dalits in the hierarchy can accentuate status concerns and render markers of social standing both fraught and contentious. Finally, the absence of a warrior or kingly cluster of castes, affords both intermediate and Dalit castes the opportunity to lay claim to a royal past-animating caste conflicts in the process (Karthikeyan 2016).

Washbrook (1989) notes that social dominance in Tamil Nadu is fragmented, with various caste groups exerting dominance over sub-regions. This fragmentation is attributed in 
great part to the ecology of the state, with caste composition and dynamics closely related to settlement patterns and forms of agriculture (Subramanian 1999:18). River valleys witnessed greater concentrations of people and division of labor, with Dalits comprising the vast bulk of landless agricultural laborers. The plains and hills, by contrast, witnessed different configurations of power and dominance in which control over irrigation tanks provided social capital and material resources to dominant castes (Mosse 1997). Given this, analysts in Tamil Nadu have to be sensitive to the regional specificities of caste relations across the state.

7 Simplifying things, we can divide Tamil Nadu into three major regions. Whilst this glosses over local specificities, they map onto the distribution of the three main Backward Caste and Dalit clusters in the state. Paraiyars (or Adi-Dravidars) are the most populous Tamil Scheduled Caste and are to be found across the state, but are most heavily concentrated in northern districts where they are pitted against Most Backward Class Vanniyars who are land-owning cultivators (Jacob and Bandhu 2009). Arunthathiyars, the lowest of the three main Dalit castes, are also dispersed across the state, but most prevalent in Western Districts where the locally dominant castes are the Gounders (Carswell and De Neve 2014). In the south, where this research is mainly based, the Dalit Pallars confront three main Backward Classes; Kallars, Maravars and Agamudaiyars who are major landowners, though in central districts of the state they are small and marginal farmers or agricultural laborers themselves (Pandian 2000). These three castes combined, have adopted the title of Thevars, and are also referred to as Mukkulathors (three castes).

8 As Pandian (2000:503) attests, the Thevars "carry the self-image of a martial community" and never have assimilated themselves into the non-Brahmin movement. The groups comprising the Thevars have a very complex history as members of a royal lineage, marauding warriors, chieftains, watchmen and dacoits. Colonial and pre-colonial descriptions of this caste cluster describe them as martial castes, but they were also found to be a settled class engaged in agriculture in the Cauvery Delta. Available reports since the 1850s indicate that these castes also carry a history of violence against lower castes (Hardgrave 1969; Pandian 2000). Their self-characterization as rulers of the land has been channeled into symbolic and electoral politics rather than educational or economic development as is the case with other groups.

9 Mines (2002:66) details how Thevars benefitted hugely from land-reforms aimed at eroding the rights of non-cultivating owners, and cemented their dominance in rural areas following Brahmin out-migration. They used temple rituals and politics to consolidate their power locally. Muthuramalinga Thevar, a scion of longstanding political rulers in Ramnad, fostered the cross-regional consolidation and identity formation of the caste cluster in his alliance with the Indian Nationalist leader Chandra Bose ${ }^{4}$ his leadership of the All India Forward Bloc in Tamil Nadu, and his struggles against the classification and repression of Thevar castes (particularly sections of the Kallars and Maravars) under the colonial Criminal Tribes Act. " "To this day," Mines (2002:66) arguesand as we shall see later-"Muthuramalinga Thevar remains a figure of identity formation for Thevars all over Southern Tamilnadu, as statues to him are erected in public places over which Thevars assert hegemony." The significance of symbolic and cultural markers for Thevar dominance and assertion renders an analysis of their portrayal in the cultural sphere imperative.

10 The Thevars co-exist with and dominate Paraiyars and Arunthathiyars in some pockets, but the main axis of caste antagonism in the south is between Thevars and Pallars. Pallars 
are the highest status and most developed of the Dalit castes in Tamil Nadu. They have high rates of education and large numbers have migrated to the Gulf for work meaning they have escaped agrarian dependency on higher castes (Lakshman 2011:142). Partly due to this, and partly due to political entrepreneurs like Dr. Krishnasamy the leader of Puthiya Tamizhagam (New Tamil Nadu)-the Pallar-based party launched in 1996-Pallars are increasingly assertive and reject markers of dependence or inferiority. In the recent past they have emulated the caste-based celebrations of Thevars and laid claim to a kingly past in ways that have escalated status concerns and conflicts (Karthikeyan 2016). It is in this context that symbols and representations in the cultural realm become politically consequential.

\section{Caste, Culture and Politics in Tamil Cinema}

11 The significance of film in Tamil society is undisputed. Indeed, film historian Theodore Baskaran (1996:ii) goes as far as to argue that: "Tamil cinema has grown to become the most domineering influence in the cultural and political life in Tamil Nadu." Film stars have a larger-than-life presence in the real world and female stars have been deified during their active period in the industry. The emergence of cinema in Tamil Nadu and its subsequent role in nurturing and promoting a Dravidian identity and politics have been the focus of several monographs (See Forrester 1976; Hardgrave 1973; Pandian 1992). That history, whilst relevant, is not our focus here and so we refer readers to the aforementioned texts.

12 Away from politics, Sreenivasan argues that there were three phases of Tamil cinema between 1931-when the first "talkie" was released-and 1985. These were the puranic, mythological and folklore period (1931-50) when films resembled the street theatre of earlier folk artists and had nothing to do with real life; the melodrama period (1951-75) which reveled in exaggeration, excessive dialogue and escapism; and finally, the move towards social realism (1976-85) when Tamil cinema came to terms with "partly realistic and anti-sentimental stories" (Sreenivasan 1993:25-26). Whilst Sreenivasan's analysis is interesting and important in charting the successive stages of Tamil cinema, it is focused on the form, production values and styles that the various films took. Were this all that there was to Tamil cinema it would not be as sociologically significant as it is.

What makes Tamil cinema stand out, however, is its umbilical link to politics. Cinema in the state grew hand in hand with the regional nationalist parties, helping to by-pass Congress-who failed to realize the significance of the medium-in the process (Hardgrave 2008:61). Congressmen never realized the power of film, says Kannadhasan, song-writer for the Tamil screen and one of the founders of the DMK. "They decried the cinema. We used it." (Hardgrave 2008:61). We would argue that Tamil films since Independence, may be divided into political as well as artistic genres. Until the 1970s the dominant political message was Dravidian. This overlapped somewhat with films showcasing a Communist or Socialist message between the late 1960s and mid-1980s. ${ }^{6}$ Following caste-based challenges to Dravidian politics from intermediate caste groups like the Thevars and Vanniyars-and their demands for a greater allocation of resources and increased political recognition-the 1990s saw the flourishing of Nativist (a form of social realism) cinema that openly celebrated and portrayed caste identities and characters. It is only in the 2010s that we see the film industry starting to acknowledge and represent Dalit struggles in films such as Madras (2014, Ranjith) and Kabali (2016, 
Ranjith). In this paper, it is the caste-centric films of the 1990s and 2000s that we focus upon, but a bit more detail on these developments in Tamil cinema is in order first.

During the 1950s Tamil film was largely used as a platform to articulate Dravidian identity and Tamil nationalism. The founding of the Dravidar Kazhagam, spearheaded by Periyar E.V. Ramasami Naicker and his "self-respect movement," in many ways had a direct influence in changing the structures of film making and inevitably led to the creation of a distinct Tamil cinema that disrupted attempts to construct a sense of a nation through cinema (Leonard 2015). These films departed from the earlier focus on religious and nationalist sentiments and articulated a rationalist critique of social ills. The founder of the Dravida Munnetra Kazhagam (DMK-Federation for the Progress of Dravidians), C.N. Annadurai was a scriptwriter and playwright. His successor, M. Karunanidhi, was a famed dialogue writer, and the most famous matinee idol of the Tamil screen-M.G. Ramachandran-was also a party stalwart until he founded the rival All India Anna DMK (AIADMK). His successor, Jayalalithaa-who was the sitting Chief Minister in 2016 at the time of her death-was a co-star of his. Both parties articulated a form of cultural nationalism using various artistic means such as stage dramas, poetry, literature, and musicals. It was with their intervention in cinema, however, that they were most successful in taking their celebration of Tamil civilization, culture and language to the masses (Perinbanayagam 1971; Sivathamby 1971, 1981).

Sreenivasan's "melodrama story period" was, of course, the period in which the DMK successfully mediated their socio-political message to the public through the medium of film. Songs, story-lines, Robin-Hood style heroes and almost subliminal references to party symbols like the flag and the rising sun, were deployed to present the party as the champion of the downtrodden. Some of the "excess dialogue" took the form of lengthy monologues in which the hero addressed the camera in lectures about socio-political values. As Rajadurai and Geetha (1996:572) note:

Cinema as a medium enabled a wider dissemination of DMK ideas and the power of the image served to bind the audience to the happenings on the screen and to induce a hypnotic identification with hero figures.

The members and leaders of the DMK identified themselves with the medium and used the stars for their election campaigns to appeal to a largely illiterate Tamil electorate. Numerous films-classically Pettralthan Pillaiya? (Are only your progeny your children? Krishnan-Panju, 1966) Nam Naadu (Our Country, Jambulingam, 1969) and Adimai Penn (Slave Girl, K. Shanker, 1969)-eulogized Annadurai as South India's Gandhi, displaying his portraits prominently on the walls of the huts of the poor and showing the DMK flag fluttering in city slums against a backdrop of songs praising his ideals. These films, thus, served the dual purpose of providing propaganda for the party whilst retaining its subaltern identity, affiliation to the poor and search for social justice (Rajadurai and Geetha 1996:573). We need to be very clear here that the subaltern identity celebrated in the Dravidian films pitted the poor against the rich or the casteless non-Brahmin against the wily and treacherous Brahmin rather than tackling caste inequalities or identities head on. Thus, speaking at a conference focused on Tamil Cinema, the noted Tamil writer A. Marx:

argued that while the Dravidian movement did overthrow a hegemonic Brahminical world view, and replace it with a progressive anti-caste agenda, their films frequently replayed regressive stereotypes of untouchables or Dalits. All too often, Marx argued, the Dalit is the butt of jokes in comedy scenes (Gopalan 1998:198). 
These films revealed the hidden caste biases of Dravidian politics and film-making. In contrast to such depictions of Dalits, as Dickey (1993) notes, the films emphasized the importance of valor and honor for the protagonists. Heroes are expected to defend the vulnerable-especially women-fight injustice and be able to protect their families and communities.

\section{Film Cast(e)s}

16 In this sense the films that we focus on are no different. The recurrent reference to the "generosity" and munificence of dominant caste heroes became a staple of neo-Nativist films in 1980s and 1990s as well. Unlike the Dravidian oeuvre, however, these films are much more explicit about the caste backgrounds of the protagonists. Srinivas and Kaali (1998:212) note how they tap into patron-client relations and serve to reproduce "caste power." In keeping with this emphasis, the heroines are expected to be chaste and faithful to preserve caste purity. There is huge significance attached to the concepts of honor (maanam) and valor (veeram) in Tamil culture, and Rajangam (2008) observes that these twin concepts have long been the basic raw material of Tamil cinema. Honor and valor are individual traits, but acquire a collective significance in Tamil politics. Honor, here, refers to the standing and status of castes in particular and is entwined with the enforcement of chastity (cf. Rege 2013). Valor, in this context, refers to men's capacity to protect their women and the honor of their family and caste (Dickey 1993). Honor in films (as in social life), thus is gendered; women protect their chastity whilst men protect their masculinity, respect and their women. Valor in films, as Rajangam shows, is bound up with a strong emphasis on traditional masculinity.

17 Cinema, thus, reflected concepts that were already in existence, but in amplifying them and presenting them to a wider audience, provided a form of cultural legitimacy to intermediate castes and to concepts of caste honor and pride (perumai). The collective expression of caste pride revolves around honor, but extends beyond this to include assertions of independence, control over others and claims to an often mythicized past. The films contributed to the socio-political visibility of landowning Backward Castes, and reinforced the prevailing "common-sense" that equated dominant castes with attributes like honor, justice, valor and power. Filmic representations across genres drew on reality, but did so in a distorted manner that showcased the "valor" and dominance of intermediate castes, implicitly neglecting or belittling lower castes who were cast as dependent upon the former (Leonard 2015). Repeated portrayals relating to particular castes (mainly Thevars and Gounders) reinforce dominant social narratives and legitimize social institutions like caste panchayats (Anand 2005). Blackburn's (1978) ethnography suggests that Piramalai Kallar (one of the castes in the Thevar category) caste headmen dominated informal institutions and were seen as more just and legitimate than the legal process. Such accounts were carried to a wider audience through the medium of cinema, and were used by members of these caste groups to justify their dominance over "lesser" castes.

18 It is, we contend, possible to chart the imbrication of cinema and caste politics by tracing alterations to the narrative depictions of caste through the 1980s. From the mid-1980s onwards, the characteristics and traits discussed above came to be portrayed as linked to particular castes. Kaali (2000), thus, discusses a dramatic departure in the 1970s during which the "phallic affirmation" of Nativism (which was part of the social realism phase 
and focused on depicting real life as opposed to myths and legends) gave way to a genre of neo-Nativity films in which the social insufficiency or "castration" of the protagonist was the dominant theme. ${ }^{7}$ Kaali (2000:174) argues that the "generic recoding" of cinematic discourses "that occurs in the late 1970s amounts, above all, to a radical refiguring of the Phallus." His fine-grained analysis of a number of films points to the emasculation of heroes in the face of feisty heroines, the complexities of modern life and the faltering hold of traditional authority.

There are some neo-nativist films where the metaphor of traditional masculinity collapses to become an object of comic relief. In the film Enga Ooru Paatukkaran (Our Village Bard, Gangai Amaran, 1987), the protagonist who is a cowherd and folk singer tames the majestic bull of the landlord not by showcasing his fierce masculine prowess but through song. Elsewhere comic characters are depicted performing some trick or the other to tame bulls. Kaali (2000:181) argues that the "Neo-Nativity Film of the transition period ... transfers mental inadequacy, normally reserved for comedians or minor characters, to the figure of the hero." The hero is, thus, neutered or subject to "social castration" (Kaali 2000:181). What Kaali does not say, is that this period of film making in the mid to late 1980s, coincided with a period in which the Dravidian project was called into question by a number of caste groups who demanded a greater say in the politics of the state (Gorringe 2012). The portrayal of emasculated protagonists from the intermediate castes, in this sense, reflected a concern that their social dominance was under threat from a political project that articulated an anti-caste ideology. The films we focus on here come after those discussed by Kaali, and might be seen as a response to and rebuttal of the themes portrayed. Indeed, they might plausibly be read as marking the end of the transition of Thevars to the centers of political power, symbolically cemented in 1993 when Jayalalithaa accorded state recognition to the annual celebrations of Muthuramalinga Thevar's anniversary (Pandian 2000).

20 Srinivas and Kaali (1998:213) note how the emphasis on the socially insufficient hero was displaced in the 1990s within the neo-nativity genre by films that reaffirmed "authority in terms of both caste and gender." Pandian (2008) likewise observes the "nativistic turn" in Tamil cinema, which saw the cinema industry begin to explore the Tamil countryside and its people, paying particular attention to rural customs, forms of worship and agriculture. Pandian argues that this shift embedded cinema in the lives of the rural masses and became "incitements to live in a particular fashion" (2008:125). He notes the ways in which people draw on film in everyday life and conversation and concludes "these films are taken by rural subjects as a way of expressing the quality of their own struggles with the substance of the countryside." We would echo Pandian's argument save for one crucial amendment. Pandian mentions in passing that these films may offer a "cinematic ode to the customs and traditions of the Piramalai Kallar caste" (2008:131), but does not probe into the impact of this caste focus on the rural or mass audience.

21 Krishnan (2008), by contrast, picks up on the issue of caste more substantively. Both he and Rajangam (2008) demonstrate that over the past three decades one particular intermediate caste cluster-the Thevar community-has regularly featured in the movies and great emphasis has been accorded to their caste standing, valor and martial prowess. The films are often intended to critique aspects of caste society and violence. Indeed, Krishnan (2008:140) argues that these new films construct the south of Tamil Nadu "as a distinct entity submerged in pre-modern violence, caste bigotry and anarchy." He points 
to the way in which the backward and barbaric south is counter-posed to the modernity and egalitarianism of Chennai in many films.

Krishnan only touches upon the social impact of these films, but the caste context in which they were screened suggests that the consequences of these portrayals deserve further attention. The fact that these films offer an "ode" to a particular caste, we would argue, is critical in understanding the interplay between caste and politics in contemporary Tamil Nadu. Such analysis is imperative given that earlier authors like Sivathamby (1981:18-19) celebrated the democratizing space of the cinema hall where "all the Tamils sat under the same roof" and "the basis of the seating is not on the hierarchic position of the patron but essentially on his purchasing power." To the extent that this ever was the case, the caste emphasis of the new films has witnessed an erosion of that democratic space.

Srinivas (2000) highlights that cinemas were never fully democratic and that caste and class hierarchies were reinforced within them. Gorringe (2005) also documents anti-Dalit violence following physical contact in Tamil cinemas. Later in this article, we chart the ways in which the valorization of caste norms and cultures serves to marginalize Dalit viewers still further. Representation, this reminds us, affects how films are received and the atmosphere within the halls (cf. Pandian 2015). The Dalit Director Ranjith, for instance, spoke of how producers warned him that his Dalit-centered films would not be well-received by the audience in southern districts (Personal Communication to Karthikeyan, 2014). For all the steamy dream sequences and song routines and despite the focus on love at first sight, therefore, Tamil cinema is strictly curtailed. The majority of plots go to great lengths to ensure the chastity of heroines and the social norms of marriage. There are numerous convoluted ways in which a seeming breach of cultural norms is avoided towards the end through narrative devices such as flash-backs.

As Anand (2003:24) concludes, Indian cinema "continues to be a major site which sustains and nurtures the caste system and brahminical social order." He points to the lack of subaltern caste heroes, and to plot lines that reinforce social values and norms. He argues that "caste and patriarchy limit the filmic imagination" (Anand 2003:17). This occurs in two ways; the inability of the directors and producers to think outside of caste, and in assumptions about audience preferences (cf. Srinivas and Kaali 1998; Pandian 2015). The imbrication of Tamil politics and cinema means that the filmic imagination has an impact on the socio-political sphere. Habermas (1987) distinguishes between "normconformative action" and "discourse" and notes how the former encourages adherence to dominant social norms. As Leonard (2015:165) argues: caste-based cinema "protects the casteist norms in their recurring narratives. This 'othering' is so overlapped that murders, honor killings, political caste alliances, and activities are considered normal and general today; so much so they seem to be produced through cinematic cultures, inadvertently." Whilst Leonard here perhaps overstates the significance of cinema, what he points towards is the way in which film scripts reinforce the positions adopted by socio-political organizations and are drawn on and reworked by actors in the real world.

M.S.S. Pandian (1996a) offered a detailed analysis of the Tamil elite's distrust of and antipathy towards the medium of cinema, but the period we are exploring arguably sees a new political elite-drawn from the Backward Castes-beginning to assume a greater role in both film and politics. This fact, we argue, has been reflected in films produced in the post-MGR period from the late 1980s. Writing about Hindi cinema, Ashis Nandy states, "their treatment of core myths and cultural concerns [is] conventionalized in ways that 
are more acceptable to the dominant culture of the state" (quoted in Pinney 1995:10). What this argument fails to account for is the changing dynamics of social dominance across India. In Tamil Nadu, thus, it is less state dominance that is reinforced and represented in films emerging from the late 1980s so much as caste. Indeed, such films often paint state institutions as corrupt or tainted in contrast to traditional power structures. Far from offering a critique of the casteist and criminal violence of the south, we will suggest, such films have served to shape and reinforce the self-image and perceptions of the Thevar castes in the south and what Srinivas and Kaali (1998:222) term "the discursive hegemonies of caste society."

\section{Madurai Formula Films}

In what follows we offer an analysis of what we call "Madurai Formula films" or 3M films (Murder, Mayhem and Madurai-though they extend to southern districts as a whole). These films, often based in Madurai, are defined by the glorification of the aruval (the sickle shaped machete) and a corresponding mythology of a society based on martial pride and caste honor. The films, explicitly or implicitly, celebrate caste dominance and become vehicles for, and expressions of, the assertion and pride of intermediate castes. Pandian (2000) details the socio-political mobilization of the intermediate castes during this period and, even where the films do not explicitly state the caste of the protagonists, the everyday markers, actions and attitudes leave the audience in little doubt as to who is being signified (cf. Krishnan 2008).

Our central contention is that the association between Thevars, violence and social dominance is reinforced and becomes the accepted "common-sense" in and through these films. Common-sense-as developed by Gramsci (1971:330n) "is the diffuse, uncoordinated features of a generic form of thought common to a particular period and a particular popular environment." As Pandian states, it forms "the ensemble of cultural presuppositions by which subaltern classes make sense of the world in which they live" (1992:30-31). Whilst akin to the construction of stereotypes as Simon (1987:5) argues, common-sense constitutes "the ordinary assumptions which people make, their way of seeing the world in which certain values seem natural and unquestionable." It is a view of the world that is subordinate to and heavily shaped by elite ideologies. The films, thus, construct a stereotype of people from the south bearing aruvals as seen in Nanmaran's quote at the head of the paper. Unlike such stereotypes, the common-sense reinforced by these films, not only portrays Thevars as a dominant and lordly or generous caste who are fearless and dangerous when crossed, but legitimizes actions that conform to this image (cf. Srinivas and Kaali 1998). The common-sense, as Simon (1987) notes, is always contested and resisted but may, for a period, shape the way in which people see themselves and others.

The situation we describe here is complicated by the fact that Thevars at this point in time, were seeking to re-imagine their history and status by appropriating existing discourses around valor and honor. ${ }^{8}$ Thus, their characterization as "criminal tribes" by the British was re-envisioned by Thevar politicians like Muthuramalinga Thevar in the 1930s as a marker of their Kingly or warrior past and need to be feared and controlled. ${ }^{9}$ The filmography in $3 \mathrm{M}$ films reinforces this attempt through the juxtaposition of national heroes such as Subhas Chandra Bose, Thevar leaders such as Muthuramalinga Thevar and the film's protagonist, or through scripts that assert the valor of the Thevars. The 
culmination of 20 years of caste-based cinema may be seen in the film Madha Yaanai Kootam (Herd of Angry Elephants, Vikram Sugumaran, 2013), which portrays the family feud of a Piramalai Kallar headman who has two wives. So powerful is the common-sense established in part through cinema, that film historian Rajan Krishnan referred to the film as a social ethnography of the everyday life of Piramalai Kallars (Krishnan 2014). The film, with blood dripping violence, has sequences and lyrics relaying a commonly held belief among the Kallars in and around Madurai about their past. The dialogue insists that the Criminal Tribes Act and Madurai Jail were designed for them as the British were unable to control them. The film's director noted that even now Kallars will greet members of the community who are released from prison with ritualized celebrations and gifts. "I am not exaggerating," he insisted, "I have captured their everyday life."10

Our argument here is not that all the films that follow this formula are the same or that they adopt similar ways of glorifying Thevars. Genres, as Srinivas and Kaali (1998:174) quote Neale (1990) as saying, are processes that are "dominated by repetition, but they are also marked fundamentally by difference, variation and change." Some of the films critique the violent sub-culture associated with Thevars. Nevertheless, all of them, continue to re-inscribe the association of Thevars with sickles, machetes and caste violence, and portray Muthuramalinga Thevar as a revered and universally admired leader. Irrespective of the directors' intent, the films are taken to celebrate the dominance of the caste cluster. ${ }^{11}$ Such processes are not unique to Tamil Nadu, but reflect the wider processes of caste consolidation and power. Sevea (2014), thus, offers a similar analysis of the way in which Punjabi films construct a Jatt-centric hegemonic code that reinforces social dominance and provides a template against which other caste groups are judged.

The power of this common-sense argument is such that it is not just Thevar actors, producers and cinematographers who adopt this formula. The commercial success of such films has made them immensely popular, which has a ripple effect that influences the way other films focused on southern Tamil Nadu are shot. Even non-Thevar directors like Gangai Amaran are not immune. His film Enga Ooru Paatukaran (Our Village Bard 1987), thus, shares none of the celebration of violence present in the other films, but the opening song still starts with a homage to Muthuramalinga Thevar and metonymically links the hero to this leader thus asserting his prowess and legitimacy.

31 To understand this genre, however, we need to start with the archetypal celebration of Thevar dominance. According to Krishnan (2008), "it is a Kamal Hassan [one of the two most famous Tamil actors, and not himself a Thevar] film of high authenticity markers called Thevar Magan (Son of Thevar, Bharathan 1992)-meaning 'Son of Thevar'-that can be said to have inaugurated the era of the south being represented as primarily a sickle bearing space." Stalin Rajangam, a Dalit cultural critic who has written extensively on the caste component and narrative structures of Tamil film concurs; he says that Thevar Magan was first of its kind with strong idioms of caste and greater glorification of caste based practices than had been the norm until that point (Karthikeyan 2011).

Taking this argument further, Srinivas and Kaali (1998) emphasize the significance of the film's soundtrack, which belied claims by the actor and producer that they were critiquing a culture of violence and domination. It was the genealogical praising of the Thevar caste in the song lyrics, they argue, that made the film such a huge box office success, and it is not surprising that the soundtrack to the film is now an essential part of the playlist at Thevar gatherings. This does not necessarily mean that the audience who 
made this a major hit subscribed to the common-sense that valorizes Thevars since it has all the ingredients of a hit movie in the casting of Kamal Hasan and music by Illaiyaraja (pre-eminent Tamil music composer), who is himself a Dalit.

Gopalan (1997) notes how there has been an escalation of violence in films across the world, and argues that this is one of the prime attractions for many viewers. In her analysis of avenging women in Indian cinema she argues that they "challenge patriarchy's normalizing overtones on the issue of gender, and constitute one of the crucial axes of spectator interests in these films" (1997:54). Unlike such films, or the classic violent encounters between good and evil, the Madurai Formula Films celebrate a violence that is rooted in, and protects, caste norms (Leonard 2015). The violence in such films is embedded in particular caste cultures and practices, as seen in the celebration of aruvals and Silambam-a martial art with sticks-that are associated in the popular imagination with Thevars.

The martial nature of Thevars is to the fore in Thevar Magan where signs, weapons and dialogue all speak to the caste's dominance. The advertising for the film reinforced the association between caste and violence. In Madurai, which has a stronger visual culture than other cities in Tamil Nadu, a 40-foot cut-out was installed showing the Thevar Magan hero brandishing an extra-large sword. More significantly still-as though to reinforce the association between life and art-the cut-out was positioned so that it faced the huge statue of Muthuramalinga Thevar in the heart of the city. During the annual "guru puja" (leader worship-processions and events to mark the anniversary of his birth), when followers of Thevar shut down the city to pay respects to and garland the statue, objections were raised against the cut-out and its glorification of violence. Consequently the sword was removed and placed behind the hoarding for a while. Due to popular pressure, however, it was later restored (Srinivas and Kaali 1998:225). Thus, as early as this, we see the imbrication of cinematic themes with popular forms of action and representation. Srivathsan captured this in his review of violence in Tamil movies:

Try this typical scene from the many recent films. Blood drips from the aruval (a large sickle) and dead men lie all around. There is neither remorse nor fear in the eyes of the male protagonist. Why should he? After all, violence is natural to the caste he belongs to, so believes Tamil cinema (Srivathsan 2007).

The dominant narrative of such films also affects how they are received. In the dramatic finale to the film, Kamal Hassan vanquishes the villain in a gory beheading scene that was greeted with whoops and cheers in the theatres of Madurai. One of the authors experienced the same film in the western city of Coimbatore where the audience were muted in their response and there were murmurings about the excessive use of violence. Whilst audience participation in the form of cheering, whistles and applause is widespread, it is the celebration of violence that stands out here. In Pandian's (2015) ethnography of film-making in Tamil Nadu he emphasizes the silence during harrowing scenes. It is our contention that the violence is celebrated here due to its association with caste dominance.

Thevar Magan was the first in a long list of films playing on this formula, including: Thevar Veetu Ponnu (The Girl of Thevar's House, Rama Narayanan, 1992); Maravan (Warrior/ Member of the Maravar Caste, Manoj Kumar, 1993); Kizhakku Cheemayile (In the Eastern Province, Bharathiraja, 1993); Periya Marudhu (The Elder Maruthu Brother (a Thevar hero), N.K. Viswanathan, 1994); Pasumpon (the village where Muthuramalinga Thevar was born, Bharathiraja, 1995); Ponmana Chelvan (Man with a Golden Heart, P.Vasu, 1996); Taj Mahal (Bharathiraja, 1999); Maayi (a name associated with the Thevars, Surya Prakash, 
2000); Diwan (Landlord, Suryaprakash, 2003); Kaalai (Bull, Tharun Gopi, 2008); Kaadhal (Love, Balaji Sakthivel, 2004); Ghilli (Risk Taker, Dharani, 2004); Sanda Kozhi (Battle Rooster, Lingusamy, 2005); Thimiru (Effrontery, Tharun Gopi, 2006); Paruthi Veeran (name of a folk hero, Ameer, 2007); Subramaniapuram (name of a locality in Madurai, Sasikumar, 2008); Goripalayam (name of a place in Madurai, Rasu Madhuravan, 2010); Saami (God, Hari, 2003); Maayandi Kudumbathar (Maayandi's (common family name among Thevars) Family, Rasu Madhuravan, 2009); Thittakudi (place name, Sundaran, 2010); Milaga (Chilli, Ravi Mariya, 2010); Aadukalam (Playground, Vetrimaran, 2011); and Sundarapandian (a name associated with Pandya kings, S. R. Prabhakaran, 2012). Our argument, again, is not that these all follow a similar plot-line, but that for all their differences, they contain references to Madurai, the obligatory use of sickles, and are replete with blood, gore and violence (see also Leonard 2015). Above all, the central idiom is the commemoration of a particular dominant caste and its customs.

The setting for the films is no accident. In the context of the rural/urban divide, Madurai is always chosen as the epitomic representation of pattikadu (rurality), as in the 1972 Sivaji film Pattikada Pattanama (Village or Town, 1972). Madurai is a former capital of the Pandya kingdom, and a seat of learning as evidenced by the holding of one of the Tamil Sangams (assemblies of poets and writers) there in the $4^{\text {th }}$ Century BC. It is an ancient city, best known for its central Meenakshi temple around which the city has grown. In earlier films, Madurai was portrayed as a site of knowledge production and center of Tamil antiquity as encapsulated in the Temple. In movies like Madurai Veeran (Madurai Hero, 1956), which made M. G. Ramachandran the matinee idol of Tamil cinema and took him to the subaltern masses, the emphasis was less on the 3M's that dominate such films today. Indeed, the script narrates the folklore legend of a subaltern hero who was hired by the Nayak King to restrain the Kallars. The more recent films based on the Madurai formula have, thus, accomplished a wholesale shift in the way Madurai as a city, and the Thevars as a caste grouping, are portrayed and imagined.

The $3 \mathrm{M}$ films cast the city as a pre-modern sphere, which simultaneously protects the glorious ancient Tamil culture by embodying its virtues, and epitomizes all the evils in society. This encoded social construction was largely the product of filmmakers from Madurai and down south, and they bring the cultural and caste/class discourses into the narrative center, indexing the fact that Madurai district constitutes the heartlands of the Thevar caste cluster. Central to this shift is the martial sport of bullfighting (Jallikattu), that archetypal symbol of traditional masculinity, caste pride, and feudalism which is most popular in Madurai district. The backward and caste-bound nature of Madurai in these films, is reinforced in accounts of the city's frenetic fans who treat film stars as demigods (Dickey 1993). It was in Madurai that fans cut off fingers and limbs and offered them to God when MGR suffered a stroke, praying for his recovery. In his analysis of recent films, Krishnan (2008) shows how Madurai is now constructed in the narrative space of Tamil cinema as the antithesis of the modern, and a place where people are still ruled by caste, clans, and kinship networks.

\section{Scripting Caste Dominance}

Krishnan (2008:141) argues that the trope of the pre-modern south is articulated by a whole range of films and media representations which contributed to its constitution. In Kaadhal (Love, 2004), for example, he sees a classic expression of the Tamil psyche as 
constituted in Tamil cinema; one which is "torn between the threatening pre-modern assertion of caste and an allegedly 'egalitarian,' free market space of modern individuals." In the film a Dalit boy who "presumes" to court a Thevar girl is grievously assaulted. Taking our cue from Krishnan's work, it is possible to discern how such tropes are reproduced in a range of different films. Thus, in Ghilli (Risk Taker, 2004), a modern couple who elope together are pursued by lorry loads of sickle-bearing, country bombthrowing men in Madurai. The implied critique of regressive caste rule here is undermined in the finale, when the hero and villain are compelled to fight each other to see who the "real man" is. Likewise, in Thimiru (Effrontery, 2006) the perception of Madurai as lawless and pre-modern is subtly reinforced by a hero who straddles both worlds and confronts his foes by reference to his origins in the violent South: "I too hail from Madurai, fight me if you have the guts." In Sandai Kozhi (Battle Rooster, 2005) the hero makes no such claim, but the film illustrates both his Thevar caste and his Madurai location to explain his ability to take on and defeat the villains from elsewhere in the state.

One question that might arise at this juncture is how the film-makers communicate the caste of the characters to the audience. In some instances, as with Thevar Magan or Chinna Gounder, the very name of the film or the character locates them within a particular community. In others, however, it is the use of attire, mannerisms and bearing that connote particular castes. One important caste marker in the context of dominant masculinity, of course, is the moustache (Gorringe and Rafanell 2007). In consideration of the physical performance of masculinity, one of the most visible and effective practicesthe styling of facial hair-comes to the fore in these films. In Thevar Magan Kamal Hassan's character returns from London with hippie-style long hair but, after the death of his father, he gives up colored clothes, rids himself of his locks and sports a big moustache that marks him out as capable of filling his father's shoes. Critically, in the film, this responsibility should have gone to the elder brother, but his masculinity is at stake due to his alcoholism and lack of valor.

The moustache here becomes synonymous with tradition and social power and this knowledge is simultaneously deployed and reinforced in films. The close association between caste standing and facial hair is emphasized in one song where even background photographs of Sivaji Ganesan (acclaimed Tamil actor)-who portrays the character of Periya Thevar-have been altered to sport an upturned moustache to be more in keeping with the thrust of the film. Few men, as Oldstone-Moore (2011) argues, have groomed themselves in complete ignorance of the social implications and, we would add, still fewer directors shoot films in ignorance of the connotations that their character's facial hair may have. ${ }^{12}$

In both Virumandi and Thevar Magan, Kamal sports side-burns and an up-turned moustache. The centrality of caste to these accounts is vividly captured in scene after scene of Thevar Magan. When Kamal Hasan's character-newly returned from London, bemoans the backwardness and violence of his Thevar brethren, Shivaji Ganesan reminds him that it was sickle- and spear-bearing Thevars who belied their wild image and were first in line to join the army started by Subhas Chandra Bose. Indeed, for all his criticism of the violent Thevars, when Kamal in Western attire is insulted and has his masculinity called into question by a group practicing a local martial art he swaps his trousers for a dhoti and dispenses punishment to them. In Virumandi, likewise, Kamal returns from abroad and finds himself embroiled in conflicts over honor and caste and engaged in 
traditional caste pursuits like bull-taming. This highlights how "valor"-as celebrated in Tamil cinema-is primarily glorified violence, which supersedes any literary, cultural or social achievements. In Vettaikaran (The Hunter, Babu Sivan, 2009), for instance, the fact that the hero is a college student is an irrelevance next to his ability to fight. "If I hit you" one of the film songs puts it, "you won't be able to bear it"-thus asserting his superiority over the villains.

The imbrication of masculinity and honor is to the fore in representations of Jallikattuthe traditional bull-taming contests in southern Tamil Nadu. In multiple films-notably Thayaikaatha Thanaiyan (The Son who saved the Mother, M.A. Thirumugam, 1962) in which MGR tames a bull with his bare hands; Murattukalai (Raging Bull-S.P. Muthuraman, 1980) where Rajnikanth's screen name "Kaalaiyan" itself refers to the bull; and in Virumaandi (Kamal Hassan, 2004) in which Kamal Hassan tames the fierce bull-the bullfighting scenes serve to legitimize a particular form of dominant masculinity. Of these three, it is only in Virumandi that the close association between caste and valor is to the fore. When Kamal Hasan's character, who has been in Singapore for many years, returns to tame a bull as though he has never been away the film suggests that caste is an innate and immutable essence rather than a code of conduct. This maps onto changes in caste composition and practice in which an emphasis on conduct gave way in the early $20^{\text {th }}$ Century to a stress on blood purity-such understandings of caste allow for wider alliances and groupings as seen in the creation of the Thevar cluster (cf. Barnett 1977). The focus on caste characteristics, however, means that no Dalits are portrayed as bull tamers.

The stress on caste traits and honor is captured in director Bharathiraja's film Mannvasanai (Fragrance of the Soil, 1983). Here bullfighting becomes the central narrative device when the father of the heroine announces that whoever tames the bull is eligible to marry his daughter. When someone from a nearby village tames the bull arguments develop over his "word of honor" and he is driven to commit suicide-having killed the bull first-owing to the disgrace and shame. This returns us to our point that these films are not mere echoes of each other-Mannvasanai is a very different film to those described above, but it still re-asserts the hegemonic narrative or common-sense that equates Thevars with honor. The Thevar caste, in other words, in the words of a song from Sandai Kozhi (2005), is a "caste that ruled for ages. A caste that nurtures warriors and patriots." 13

It is important to note here that such films are not confined to the south. In the film Cheran Pandian (1991), it is the intermediate caste of Gounders-who are dominant in the north-western regions of the state-who feature. When the village head Periya Gounder's untamed bull enters the arena the images of the bull running in slow motion and the pride in Periya Gounder's face are juxtaposed on the screen, the bull mauls an innocent onlooker who was thrown inside the arena, whereupon the protagonist enters and tames the bull. Unable to digest the fact that his bull has been tamed and that his caste pride has taken a knock in public, Periya Gounder takes a gun and shoots the inadequately ferocious bull. Films featuring Gounders and Vanniyars, however, tend not to have the same ostentatious celebration of violence and sickles seen in the Thevar based films of the south.

Unlike the films discussed by Kaali (2000) in which the heros can never achieve manhood and remain tragic characters, $3 \mathrm{M}$ films reaffirm the tropes of masculinity and honor. Now, exceptions to the rule in these films see the audience collapse into laughter at these scenes, marking their recognition of the hegemonic norm. The transition from the 
emasculated, insufficient male described by Kaali, to the virile protagonist of the films discussed here is epitomized in Virumandi. The central protagonist-played by Kamal Hasan-is a tragic figure in many ways, but his masculinity, prowess and valor are not in question. In one humorous scene Kamal stands between the Thevar and Nayakkar (a Backward, land-owning caste above Thevars in the status hierarchy, but socio-politically weaker than them) caste groups, taunting the latter. Though one could argue that he is emasculated here by the intervention of the police who prevent him from attacking his opponents, his virility is affirmed when he challenges the Nayakkars to a sickle fight and an old grandmother wielding an aruval is the only one to respond to his challenge, thus affirming the inadequacy of the Nayakkar caste men. ${ }^{14}$

Indeed, the most common trigger for conflict in Tamil films, and especially in the Madurai Formula ones, is when the honor or manhood (aanmai) of the hero or his family is questioned or challenged. Crucially for our argument, the cinematic offerings most closely adhering to the $3 \mathrm{M}$ formula have not only provided a discourse through which to discuss caste, but also offered a template according to which dominant castes have sought to reimagine and reinforce their dominance. In metonymically linking film stars to political figures, such films suggest that Thevars have a right and a duty to uphold their honor. For example, the title song in the film Karimedu Karuvayan ${ }^{15}$ (Karuvayan from the Karimedu area of Madurai, Rama Narayan, 1986) based on Madurai's folk hero, starts with an invocation to the goddess Meenakshi before the camera slowly moves around capturing Madurai's prominent landmarks, lingering on the temple in the heart of the city before showcasing the Vaigai River, the causeway, Albert Victor Bridge and so on. When the song comes to its last and final stanza that runs-"He (Thevar) is the master of the southern land, lion of the south who came in changed guise"-the camera pans towards the larger than life-size statue of Pasumpon Muthuramalinga Thevar in the citycenter until it fills the entire screen before tilting backwards to the flowing Vaigai. The song celebrates Thevar as a proud, ferocious and just leader. Crucially, it joins a long list of films celebrating traditional figures and patterns of authority, and ties those imaginings to real places and contested symbols such as the Thevar statue-site of the annual guru puja by the Thevar caste cluster which has received state recognition and routinely brings the city to a standstill. Subsequent to this state recognition there has been an explosion of films using explicit caste markers and names in an overt expression of dominance.

The films, thus, buttress Thevar claims-as articulated in public meetings, processions, history books and websites-to an exalted and kingly past and a status deserving respect in the present. You are best advised, the films suggest, not to cross them in any way. The influence of Thevar Magan in this regard, can be seen in many movies which came later, for example almost in a similar vein, a song in the film, Sanda Kozhi (Battle Rooster, Lingusamy, 2005) interposes images of the village headman (Thevar) and his son watching cocks, bulls and rams fighting in the ring with shots of the headman swinging a sickle or giving alms to the poor and the needy. The dominant caste landlords, we are thus reminded, are patriarchs who are equally at home with violence as with benevolent patronage (cf. Srinivas and Kaali 1998). 


\section{Creating and Contesting Caste Common-sense}

What this example, and the prominent role of cinema in Tamil politics, tell us is that films have an important role and life outside the cinema halls. Pandian argues that film has "come to provide a language for the social life of kinship and attachment" (2008:131). Certainly, many of these films have been adopted by Thevars in southern Tamil Nadu through posters, symbols, banners and the playing of film songs and dialogue at cultural events. As Kaali (2000:186) argues, "identification with ego-ideals on the screen need not inevitably entail 'misrecognitions of self,' but, in many cases, could involve elements of empowerment" and identity change. The portrayal of Thevar violence and valor on screen and their positive reception, serve to embolden Thevars and legitimize their use of violence. ${ }^{16}$ The outpouring of films coincided with the period in the 1980s and 1990s in which they secured political significance and reacted aggressively to Dalit assertion (Pandian 2000). The norms portrayed in 3M films, in other words, are not just screen fictions: Tamizhmurasu (2008) documents caste-based, Thevar-vs-Dalit atrocities in Madurai District at this time. He details the murders of 27 Dalits by Thevars between 1983 and 2005 in Madurai District alone-common to all the killings is the use of excessive violence carried out at close quarters using machetes or sickles. The violence in each case was clearly intended to send a message to others about the dominance and impunity of Thevars.

Following police firing on Pallars in 2011, Teltumbde quotes Tamil social historian V. Geetha to note:

Ever since the AIADMK under MGR and later on under the present Chief Minister J. Jayalalithaa have chosen to patronize the Thevars (and the other sub-castes that are linked to them, including the Kallars and the Maravars), community leaders in the southern districts have reaffirmed their caste authority and hegemony by taunting, insulting and inflicting violence on Dalits who dare to defy their diktats. Political support in fact has earned them an impunity that is explained away in terms of their so-called "primeval" will to acts of violent anger (Teltumbde 2011).

At the time of writing, in 2016, Tamil Nadu was still reeling from the cold-blooded murder of a Dalit man, Sankar, in broad daylight following a love marriage to a Thevar woman (The Economic Times 2026). The murder-caught on CCTV-was widely condemned, but the two main Dravidian parties remained silent on the topic. At a larger socio-political level, we argue, the explicit or implicit eulogizing of Thevar militancy in both films and staged social events, combined with state support, has given a psychological edge to the dominant castes in contemporary caste dynamics.

It is no surprise, we argue, that these films coincided with a resurgence of anti-Dalit violence including murders, beatings and riots by Thevars as documented by Human Rights Watch (1999). Such clashes are not new-dating back to the Mudukulathur riots of 1957 at least ${ }^{17}$-but the violence of the 1990s was a direct response to Dalit assertion and attempts to escape dependence. "Between July 1995 and June 1996, clashes between Thevars and Pallars resulted in large-scale destruction of property, loss of life on both sides" (Human Rights Watch 1999:84). These riots, the report notes, point to shifting constellations of power and the increasing independence of Dalit castes as seen in the emergence of the two main Dalit parties-Puthiya Tamilagam and Viduthalai Chiruthaigal Katchi (Liberation Panther Party) around this time. 
51 The link between $3 \mathrm{M}$ films and such violence is clear even if there is no causal chain. Songs like Potri Paadadi Pennae/Thevar-kaladi manne (Praise the land touched by Thevar's feet) and Ayya Nam Thevar Ayya (Master, our Thevar Master) are routinely played by Thevar households during family rituals and ceremonies and village festivals, but especially during the birth anniversaries of Muthuramalinga Thevar and other caste heroes. Anand (2005) notes how the public performance of these partisan hits resulted in conflicts in student hostels. More alarmingly, Thevar Magan was deliberately used to mobilize Thevars during the Pallar-Thevar riots that flared up repeatedly between 1995 and 1998. Thevars in riot torn villages screened the film (Rajangam 2008:60), and its songs were used to instigate inter-caste violence (Ravindran 2008). ${ }^{18}$ During the same period in Kovilpatti during the local Hindu festival there was a row between the Dalits and the Nayakkars which became a caste clash. The riot, which began as a Dalit against Nayakkar feud, soon assumed a different hue when Thevars were brought in from nearby villages to attack the Dalits. They were given shelter in Nayakkar-owned marriage halls where the Kamal starrer was screened. This happened everywhere and, in the late 1990s from schools to colleges, Thevar youth would sing the songs of the film when they encountered young Dalits (Rajangam 2008:61). As recently as 2012, during fieldwork on caste politics, the authors visited villages where caste conflict had arisen around the music played at village festivals.

52 Anand (2005) vividly captures contemporary political dynamics in the following account of responses to Kaadhal (Love, 2004) - a low budget film about a romance between a couple of unspecified castes who are, nevertheless identifiable as a Thevar girl and a Dalit boy. When the couple is discovered, the girls' family beat the boy to a pulp. Crucially, for our argument, the representations on screen are transposed into the caste politics of everyday Tamil Nadu:

[A] friend who watched Kaadhal in a Madurai cinema talked of how Thevars-the dominant "backward caste" of the southern districts-in the hall shouted aloud: "Fuckers, this will be your fate if you think you can get our girl." Dalits watching the movie in the southern districts were intimidated both by the depiction of the hero and by the participative enthusiasm of the Thevars among the audience (Anand 2005).

Anand's comments, as noted in our account of the different reception accorded to Thevar Magan in Madurai and Coimbatore above, highlights the significance of audience configuration. Given that melodrama as a cultural mode encourages identification with the victim (Anker 2005), we might expect audiences elsewhere to empathize with the Dalit victims and condemn casteist violence. Anker (2005:23), however, argues that melodrama is also "a pervasive cultural mode that structures the presentation of political discourse." In the Tamil context, the Madurai Formula's focus on caste, honor and violence reiterates "the intimate bond between region (Madurai), caste, violence and masculinity" (Leonard 2015:159).

53 The films, in other words, fed into the construction of Thevar caste pride (cf. Pandian 2000). Thus, when a film cast them in a less glorified and flattering light they were quick to respond. In Madurai, Theni and Kovilpatti districts, for instance, cinema halls were damaged during the screening of Bharathi Kannamma (1997) the story of a cross-caste love affair which depicted a member of the Thevar caste falling at the feet of the Dalits as a punishment for his own mistake. This provoked the Thevars and they damaged theatres by pulling up the seats and pelting stones at buses in their anger (Rajangam 2008:62). Caste and politics, it is clear, are thoroughly intertwined whether at 
the level of institutional politics or mobilization along community lines. In like manner, as Anand, points out:

In the last five years, marginal castes hitherto invisible in Tamil cinema, such as Vanniyars, have found a space via filmmakers like Thangar Bachan (Azhagi, Solla Maranda Kathai and Thendral). Their rise coincides with the coming of age of the Vanniyar-based Pattaali Makkal Katchi [Toiling People's Party] led by S. Ramadoss (Anand 2005).

Caste assertion, in other words, is both reflected and reinforced through film. The common-sense of caste is reinforced not just through celebrations of Thevar dominance but in the denigration of Dalits in the films above. In the majority of scripts they are seen as subservient. This emphasis on masculine violence precluded Dalits from assuming the role of protagonists since, as Anandhi, Jeyaranjan and Krishnan (2002:4399) note, there has historically been a "denial of masculine identity to Dalit men in the non-household domain." Thus, in associating valor with violence, these films serve to marginalize Dalits. Whilst these films have been portrayed as authentic and as accurately capturing facets of rural life, the cinematic portrayal of the dominant caste man of violence with a handlebar moustache serves to normalize such features. ${ }^{19}$ The idiom, of course, only applies to dominant caste men. Indeed, until relatively recently Dalits were prevented from wearing ironed shirts and sporting styled moustaches and none of the characters portraying Dalits on screen are shown with twirled moustaches. Art here, both imitates and reproduces social life: In Madurai district in the 1990s, dominant castes retaliated against Dalits who dared to grow martial facial hair (Thirumaavalavan 2004). One Dalit who sported a big moustache, for instance, was taken to the village square in Errampatti (a village in Madurai District) and shaved in front of onlookers. Anandhi et al. (2002) attest that Dalit mobilization in the 1990s created a new masculine identity based upon challenging caste dominance, and it is true that the Viduthalai Chiruthaigal Katchi immortalized this incident in a folk song which goes: "In that age in Madurai they humiliated those of us with handlebar moustaches; But in this age, almost one crore [10 million] Panthers move across Tamil land sporting big sickle like moustaches" (Field notes, 2012). ${ }^{20}$

Faint traces of anti-caste campaigns are seen in the $3 \mathrm{M}$ plots, but these are strictly curtailed. Vijaya Kumar's character in Bharati Kannama (Cheran, 1997), for example, upbraids a Thevar youth for raping a Dalit woman and demands that he fall at her feet. In a famous passage he asks: "Who is a Thevar?" His response is that wielding a sickle and twirling your moustache are not enough to be considered as such. Instead he paints a picture of a benevolent patron. Importantly, during this speech he gestures to the passive line of Dalits standing aside with arms folded and heads bowed and speaks of them as nomadic tribes-people incorporated into the villages as agricultural and menial laborers. ${ }^{21}$ Thus, even in the overt condemnation of caste violence, Dalits are stripped of their agency and rendered passive recipients. Other popular film tropes similarly conspire to relegate Dalits to the margins. The emphasis on bull-taming is a case in point, since Dalits were historically barred from taking part in such contests and have only begun to enter them since the Dalit struggles of the 1990s.

The reel life focus on bull-taming as an arena of caste pride and honor, was tragically played out for real on April, 9, 1995 when a Dalit was beheaded for entering the bulltaming ring in Oorcheri village in Madurai District (Madhava Menon and Banerjea 2003:124). Even today traditional bull-fights in Madurai district are marked by caste and contests over status. Since those who tame bulls are seen to have tamed the owner, according to Rajangam (2014), Dalits and numerically weaker castes like Vannars and 
Asaris are still passive spectators at most events. Where they have fought for the right to participate, caste tensions increase as a result. ${ }^{22}$ Their continued subordination and subservience in Tamil films, from this perspective, serve to reinforce caste pride for Thevars even as it reminds Dalits of their place (Karthikeyan 2013).

Despite a number of Dalit actors and directors and a global icon in music director Illaiyaraja, the Dalit upsurge of the 1990s has yet to be reflected cinematically in like manner. Srinivas and Kaali (1998:221-22) discuss Sekar's Onna Irukka Katthukkanam (We Must Learn to Live as One, 1992) which openly discusses Dalit questions. However, not only is it a comedy, it stands as an exception which "shatters the stability of the delicate logistical constructs around which are organized the discursive hegemonies of caste society" (Srinivas and Kaali 1998:221-22). Srinivas and Kaali are right to point to the utopian aspirations embodied in the film, but it is important to stress that for the most part Dalits are not only portrayed in humiliating ways, their options in film making are limited. When the name of A. L. Vijay's film starring the actor Vikram was announced as Deiva Thirumagan (God's Chosen Son, 2011), there was an outcry from Thevar groups who have trademarked that phrase for Pasumpon Muthuramalinga Thevar and were particularly infuriated by the fact that the main actor in question was a Dalit who is celebrated by Pallar youth as one of their own. Eventually the film was released as Deiva Thirumagal (God's Chosen Daughter) instead. The fact that this latter term was acceptable highlights both the significance accorded to Thevar, and the interplay between caste and patriarchy (cf. Srinivas and Kaali 1998:214; Economic and Political Weekly 2013).

Here, however, the contested and contingent nature of the common-sense view becomes transparent. Gramsci (1971:326) notes how the dominant worldview also contains seeds which may lead to the germination of resistance. Thus it is, that at the same time as Thevars complained about Bharati Kannamma, Dalit movements such as the VCK protested vehemently about scenes showing the protagonist begging for food and being overly compliant to the landlord. They also lobbied successfully to have the song Ayya Nam Thevar Ayya (Master, our Thevar Master) excised from the film. More recently, followers of militant Pallar founder-leader of Federation for the Progress of Tamil People, John Pandian, smashed glass cases in a cinema hall during a screening of C. Sundar's Murattukalai (2012), claiming that aspects of the dialogue targeted their leader. ${ }^{23}$ Although Thirumavalavan-leader of the VCK-has appeared in cameo roles in a number of Tamil nationalist- (not caste-)themed films, it is in these protests against films that Dalit mobilization was most obviously reflected until the emergence of Ranjith as a director in 2013.

Grasping the inter-relationship between filmic eulogies and caste violence, Dalit movements have sought to contest dominant depictions of caste pride and valor. This is best illustrated in the controversy surrounding Kamal Hassan's film Virumandi (2004). Initially it was due to be called Sandiyar, which means a violent rogue and has connotations linking it to the Thevar caste. Dr. Krishnasamy of Puthiya Tamilagam vociferously objected to the film. He argued that "Thevar Magan 'drove a wedge' between the two communities, resulting in violent clashes and virtually threw the southern districts into a cauldron of communal tension; he said the film-star's latest venture would only revive the notorious 'aruval' (sickle) culture, shattering communal peace."24 Justifying his stance, Dr. Krishnasamy argued that "in Tamil Nadu, cinema is closely linked with social and political life, unlike in any other state." ${ }^{25}$ In the end a compromise 
was reached in which the title of the film was changed and the plot line subtly altered to avoid being seen as a direct follow-up.

Despite this, Virumandi was widely seen as a sequel to Thevar Magan and, belying the actor's claims of neutrality, debates about the film ended up with "Puthiya Tamilagam opposing it and splinter groups of the All-India Forward Bloc [a Thevar front] and some Mukkulathor outfits offering to provide protection., ${ }^{26}$ Further undermining the anticaste violence subtext of the film, the movie featured a provocative snippet in which the lead character Virumandi is called "Sandiyar" in one exchange and, when he corrects the character they reply: "You will always be Sandiyar to us." There was also a song of the same name flying in the face of the compromise agreed to. The launch party was held in Madurai as if to reinforce its $3 \mathrm{M}$ leanings, and prominently featured aruvals.

The extent to which these metonyms inform everyday common-sense, may be seen in the actions and assumptions of police officers and journalists. As the authors of this paper have experienced, it is not unusual for protagonists in caste clashes to be referred to using short-hands that reflect the 3M formula: They will, thus, speak of Thevars as the " aruval party" (sickle group) or "meesai party" (moustache group) being opposed to the SCs (Scheduled Castes). At times, indeed, words can be dispensed with in favor of the imaginary twirling of a moustache to indicate Thevars. Whether the films endorse or critique the violence in the plot-lines, in other words, they reproduce a symbolic world in which the dominance, standing and valor of intermediate castes is unquestioned. The powerful influence of the common-sense as enunciated here is seen in the reported rise of honor killings throughout the state (Dorairaj 2009), which have been explicitly linked to the celebration of caste violence and dominance in films (Leonard 2015). ${ }^{27}$ The ways in which film plots feed into politics was graphically illustrated in 2013, when Dr. Ramadoss, the founder-leader of the Vanniyar centered Paatali Makkal Katchi (Toiling People's Party) which was behind the violence against Dalits in Dharmapuri, publicly endorsed Kumki (Elephant Herdsman, 2012) for its implied critique of cross-caste marriage (Karthikeyan 2013). Tamil films, thus, buttress the supposed virtues of caste traditions and purity.

61 Perhaps the biggest testament to the power of this caste common-sense, and an indication of its reach, is that Dalit and other caste outfits have started to adopt a language of caste pride and valor that echoes the films we have been discussing (cf. Pandian 2000). A symbolic representation of the caste pride now espoused by Dalits was seen in wall paintings in 2010 when Thirumavalavan-the leader of the Paraiyar-based Liberation Panthers-was referred to with the more honorific suffix Thirumavalavar (Gorringe Field notes 2010). Thus, the central emphasis on caste pride, valor and honor in the $3 \mathrm{M}$ films has arguably had a performative effect that has served to engender new forms of caste expression, representation and identity in contemporary Tamil Nadu. This has now, begun to inform cinematic representations also, as seen in Ranjith's 2016 film Kabali, in which Tamil superstar Rajinikanth reads Dalit books, speaks of Ambedkar, and portrays a strong Dalit hero. As Stacy (1991) notes, audience identification with themes and characters may entail "processes of transformation and the production of new identities, combining the spectator's existing identity with her desired identity" (in Kaali 2000:186-87). In the Madurai formula films, we contend, sections of the upwardly mobile Thevar caste found an articulation of virility, valor and unbending dominance which they could mimic and aspire towards. Crucially, as Anandhi, Jeyaranjan and Krishnan (2002) observe, this has become a template for other castes-including Dalits-to follow. 


\section{Conclusion}

problems of the south, but urges us to be wary of self-legitimizing discourses and narratives of modernity, which offer modern political rationality, and the "progress" of capitalist modernity as the only alternatives to savagery and caste bigotry. In a passage worth quoting at length he notes:

It is my argument that the southern caste conflicts of the nineties [are] the main reason why the south has come to be portrayed as backward, less civic and given to sickles and primordial violence. While this may make sense in the popular "logic" of imagination, critical thought should hasten to warn of the dangers of stereotyping and the limitations of representative practices of cinema, particularly given the salience and circulation of cinema in Tamil Nadu (Krishnan 2008:150).

This, we feel, is an important argument for a number of reasons. Firstly it places the new wave of films against the backdrop of violent clashes between Backward Caste Thevars and Scheduled Caste Pallars; secondly it carries an implied criticism of Thevar violence; and finally it cautions that the celebration of sickles, valor and violence could be selffulfilling.

We will deal with each point in turn. Firstly we welcome the attempt to contextualize such films within the social relations of south Tamil Nadu. What we would add is that the riots of the 1990s were merely the visible manifestation of Thevar caste dominance, which continues into the present day as seen in the problems surrounding the holding of reserved panchayat elections in Thevar strongholds. Secondly, we agree that the intention of the films may have been to decry the backwardness of the south, but we argue that the effect was if anything the reverse. Films, once they are released, have a life of their own that is beyond the intentions and direction of the film makers. In this sense, we find Krishnan's reading of the films somewhat limited. At several points, for instance, he makes arguments to the effect that:

while the modern state is compromised by electoral politics allowing such hooligans to exercise control over politicians or elected representatives, it is nevertheless capable of producing neutral individuals like Saami [an honest and heroic policeman from the 2003 film of the same name] in its administration who can annihilate the anti-state bodies and their caste-criminal networks (2008:142).

What is omitted from this analysis is the fact that Saami only succeeds in smashing the criminal nexus by adopting precisely the same tactics and approach that Krishnan decries. In an implied critique of the formal institutions of democracy, Saami beats the gang by becoming the biggest rowdy in town. This is best exemplified in one stirring scene where a sickle-bearing and stone-wielding "southern" mob confront the lines of police officers armed with lathis and guns and pour scorn on their orderly nature. Saami asks the crowd to disperse and, when they refuse, he signals to his men who rush forward carrying supplies of sickles, stones and sticks, which the police then proceed to arm themselves with to the astonishment and terror of the criminal mob who are soon put to flight. Caste violence and dominance, here, can only be tamed from within.

Consequently, we would also temper Srinivas and Kaali's (1998:215) reading of Thevar Magan. They argue that the hero's courting of arrest at the end of the film "signifies a total submission of the authority of the village community to state power." In line with our analysis of Saami, however, the scene could be read as asserting that only a Thevar 
can uphold the law. In any case, the symbolic submission to the state occurs at a time when Thevars were being assiduously courted by both Dravidian parties and gaining socio-political influence (cf. Human Rights Watch 1999). We have dealt with this issue at some length because it has a critical bearing on the third facet of Krishnan's argument about self-fulfilling prophesies. Here we would not just agree with his note of caution but argue that this has already happened to a great extent, as he himself notes by referencing the use of Thevar film-songs at caste functions and events. The portrayal of a brigandlike, violent caste culture may well have been intended to prompt introspection and reform in the Tamil South. Instead it has fuelled caste conflicts, resulting in an exaggerated sense of caste pride and an emphasis on caste symbolism that has periodically pockmarked the southern regions of the state with violence, and continues to inform caste politics today.

In Pandian's (2008:132) study of the Cumbum Valley, he notes how one respondent upbraided another: "You shouldn't speak about cinema," Malai said -probably with the integrity of my anthropological interview on his mind - to which Bose retorted sharply: "Dey, they're making cinema about nothing but our culture!" Pandian fails to note the speaker's caste, but if he is speaking about Madurai formula films, Bose cannot be anything other than Thevar. Combining Pandian's (2008) insights on the interpenetration of cinema in everyday life with these studies on southern films, we can see that there was a symbiotic relationship between the portrayal of intermediate caste valor on the silver screen and their mobilization around such concepts in the political sphere. The "traditional violence" that Krishnan condemns and counter-poses to the liberal and rational modernity of the city, is in itself a modern revival if not creation. It owes much to its encouragement and circulation through that most modern of media: film.

Pandian (2000:514) concludes his article on caste conflicts in Tamil Nadu by insisting on the need "to be sensitive to specific histories of different castes that are involved in conflicts." Such histories, we would add, should also be sensitive to the cultural constructions and projections of different castes and their role in the creation and celebration of particular categories and identities that constitute the common-sense of caste. The deleterious consequences of a culture that emphasizes masculine caste pride and celebrates caste honor and violence are all too evident in the caste conflicts and honor killings that characterize contemporary Tamil politics (Leonard 2015). If we are to see a decline of such violence, we do not need more films that deplore caste violence whilst reproducing it in glamorized form, but a critique of the common-sense which such films reflect and help to reproduce.

\section{Filmography}

\section{Dravidian Filmography}

1956: Madurai Veeran (Madurai Warrior, D.Yoganand)

1962: Thayaikaatha Thanaiyan (The Son Who Saved the Mother, M.A. Thirumugam)

1966: Pettralthan Pillaiya? (Are Only Your Progeny Your Children?, Krishnan-Panju)

1969: Nam Naadu (Our Country, CP.Jambulingam)

1969: Adimai Penn (Slave Girl, K.Shankar)

\section{Communist Films}

1981: Sivappu Malli (Red Jasmine, Rama Narayanan) 
1983: Kann Sivanthaal Mann Sivakkum (When Eyes Turn Red, the Soil Too Will, Sreedhar Rajan)

1997: Aravindhan (A Name, T. Nagarajan)

2003: Anbe Sivam (Love is God, C. Sundar)

\section{Filmography on Caste}

1972: Pattikada Pattanama (Village or Town, P. Madhavan)

1983: Mannvasanai (Fragrance of the Soil, Bharathiraja)

1986: Karimedu Karuvayan (Karuvayan (a folk hero) from Karimedu (a place in Madurai), Rama Narayanan)

1987: Enga Ooru Paatukkaran (Our Village Musician, Gangai Amaran)

1991: Cheran Pandiyan (historic Tamil kings, K.S.Ravikumar)

1992: Chinna Gounder (Young Gounder (a dominant caste), R.V.Udhayakumar), Periya Gounder Ponnu (Daughter of Periya Gounder, Erode Soundar) Thevar Magan (Son of Thevar, Bharathan), Thevar Veetu Ponnu (Daughter of the Thevar House, Rama Narayanan)

1993: Maravan (a martial caste, Manoj Kumar) Kizhakku Cheemayile (Eastern Land, Bharathiraja)

1994: Periya Marudhu (The Elder Maruthu Brother (Thevar hero), N.K.Viswanathan)

1995: Pasumpon (Birthplace of Muthuramalinga Thevar, Bharathiraja)

1996: Ponmana Chelvan (Man with a Golden Heart, P.Vasu)

1997: Bharathi Kannamma (Bharathi's Love, Cheran)

1999: Taj Mahal (Bharathiraja)

2000: Maayi (a name associated with the Thevars, Surya Prakash)

2003: Saami (God, Hari); Diwan (Landlord, Suryaprakash, 2003); Solla Maranda Kathai (The Story I Forgot to Tell, Thangar Bachan)

2004: Kaadhal, (Love, Balaji Sakthivel,) Ghilli (Risk Taker, Dharani); Thendral (Breeze, Thangar Bachan)

2005: Sanda Kozhi (Battle Rooster, Lingusamy)

2006: Thimiru (Effrontery, Tharun Gopi)

2007: Paruthi Veeran (Name of a Folk Hero, Ameer)

2008: Kaalai (Bull, Tharun Gopi) Subramaniapuram (name of a locality in Madurai, Sasikumar)

2009: Maayandi Kudumbathar (Rasu Madhuravan, 2009), Vettaikaran (The Hunter, Babusivan)

2010: Goripalayam (name of a place in Madurai, Rasu Madhuravan), Thittakudi (place name, Sundaran), Milaga (Chilli, Ravi Mariya)

2011: Aadukalam (Playground, Vetrimaran)

2012: Sundarapandian (a name associated with Pandya kings, S.R.Prabhakaran), Murattukalai (Raging Bull, Sundar. C)

\section{Dalit filmography}

2014: Madras (Ranjith)

2016: Kabali (name widely used by Dalit and Fisher communities, Ranjith) 


\section{BIBLIOGRAPHY}

Anand, S. 2005. "Politics, Tamil Cinema Eshtyle." Outlook, 30 May, 2005. Retrieved Semptember 30, 2013 (http://www.outlookindia.com/article.aspx?227523).

Anand, S. 2003. "Eating with Our Fingers, Watching Hindi Cinema and Consuming Cricket." Pp. 424 in Brahmans and Cricket, edited by S. Anand. Pondicherry: Navayana.

Anandhi, S., J. Jeyaranjan and Rajan Krishnan. 2002. "Work, Caste and Competing Masculinities: Notes from a Tamil Village." Economic and Political Weekly 37(43):4397-406.

Anker, Elisabeth. 2005. "Villains, Victims and Heroes: Melodrama, Media, and September 11." Journal of Communication 55(1):22-37.

Barnett, Steve. 1977. "Identity Choice and Caste Ideology in Contemporary South India." Pp. 393415 in The New Wind, edited by K. David. The Hague: Mouton Publishers.

Baskaran, Theodore. 1996. The Eye of the Serpent: An Introduction to Tamil Cinema. Madras: East-West Books.

Berreman, Gerald. 1963. Hindus of the Himalayas. Berkeley: University of California Press.

Blackburn, Stuart. 1978. “The Kallars: A Tamil ‘Criminal Tribe' Reconsidered.” South Asia: Journal of South Asian Studies 1(1):38-51.

Carswell, Grace and Geert De Neve. 2014. "T-shirts and Tumblers: Caste, Dependency and Work under Neoliberalisation in South India." Contributions to Indian Sociology 48(1):103-31.

Dickey, Sara. 1993. Cinema and The Urban Poor in South India. Cambridge: Cambridge University Press: 1993.

Dorairaj, S. 2009. “Demons and gods.” Frontline 26(17). Retrieved August 25, 2014 (http:// www.frontline.in/static/html/fl2617/stories/20090828261702200.htm).

Economic and Political Weekly Editorial. 2013. "Fighting Caste, Fighting Patriarchy." Economic and Political Weekly 48(29):8.

Forrester, Duncan. 1976. "Factions and Film Stars: Tamil Nadu Politics since 1971." Asian Survey 16(3):283-96.

Gorringe, Hugo. 2005. Untouchable Citizens: The Dalit Panthers and Democratisation in Tamilnadu. New Delhi: Sage.

Gorringe, Hugo. 2012. "Caste and Politics in Tamil Nadu." Seminar 633(May 2012):38-42. Retrieved June 20, 2017 (http://www.india-seminar.com/2012/633/633_hugo_gorringe.htm).

Gorringe, Hugo and Irene Rafanell. 2007: “The Embodiment of Caste.” Sociology 41(1):97-114.

Gopalan, Lalitha. 1997. “Avenging Women in Indian Cinema.” Screen 38(10):42-59.

Gopalan, Lalitha. 1998. “Tamil Cinema: History, Culture, Theory.” Screen 39(2):196-200.

Gramsci, Antonio. 1971. Selections from the Prison Notebooks of Antonio Gramsci. Edited and translated by Q. Hoare and G. Nowell Smith. London: Lawrence and Wishart.

Habermas, Jurgen. 1987. The Theory of Communicative Action. Vol. 2. Cambridge: Polity. 
Hardgrave, Robert. 1969. The Nadars of Tamil Nad: The Political Culture of a Community in Change. Berkeley: University of California Press.

Hardgrave, Robert. 1973. "Politics and Film in Tamil Nadu: The Stars and the DMK." Asian Survey 13(3):288-305.

Hardgrave, Robert. 1979. When Stars Displace Gods: The Folk Culture of Cinema in Tamil Nadu. New Delhi: Usha Publications.

Human Rights Watch. 1999. Broken People. Compiled by S. Narula. New York: Human Rights Watch. Jacob, Preminda. 2009. Celluloid Deities. New Delhi: Orient Blackswan.

Jacob, T. and P. Bandhu. 2009. Reflections on the Caste Question. Ootacamund: Odyssey.

Kaali, Sundar. 2000. "Narrating Seduction: Vicissitudes of the Sexed Subject in Tamil Nativity Film.” Pp. 168-90 in Making Meaning in Indian Cinema, edited R. Vasudevan. New Delhi: Oxford University Press.

Karthikeyan, D. 2011. “'Madurai Formula' Films and Social Realities.” The Hindu, May 2. Retrieved December 9, 2016 (http://www.thehindu.com/todays-paper/tp-national/tp-tamilnadu/maduraiformula-films-and-social-realities/article1984785.ece).

Karthikeyan, D. 2013. “When Reel Life Depicts Love Marriages as Unreal.” The Hindu, July 16. Retrieved October 28, 2015 (http://www.thehindu.com/todays-paper/tp-national/tp-tamilnadu/ when-reel-life-depicts-love-marriages-as-unreal/article4919482.ece).

Karthikeyan, D. 2016. "Contentious Spaces: Guru Pujas as Public Performances and the Production of Political Community." Pp. 194-216 in From the Margins to the Mainstream, edited by H. Gorringe, R. Jeffery and S. Waghmore. New Delhi: Sage.

Krishnan, Rajan. 2008. “Imaginary Geographies: The Makings of 'South' in Contemporary Tamil Cinema." Pp. 139-53 in Tamil Cinema: The Cultural Politics of India's Other Film Industry, edited by S. Velayutham. Abingdon: Routledge.

Krishnan, Rajan. 2014. "Foreword" in Subagunarajan, V.M.S. Saathiya Cinemavum Kalachaara Cinemavum (Caste Cinema and Cultural Cinema). Chennai: Kayalkavin Publications.

Lakshman, Narayan. 2011. Patrons of the Poor: Caste Politics and Policymaking in India. Delhi: Oxford University Press.

Leonard, Dickens. 2015. "Spectacle Spaces: Production of Caste in Recent Tamil Films." South Asian Popular Culture 13(2):155-73.

Madhava Menon, N. R. and D. Banerjea. 2003. Criminal Justice India Series. West Bengal National University of Juridical Sciences: Allied Publishers.

Mines, Diane. 2002. "Hindu Nationalism, Untouchable Reform, and the Ritual Production of a South Indian Village.” American Ethnologist 29(1):58-85.

Mosse, David. 1997. "The Symbolic Making of a Common Property Resource: History, Ecology, and Locality in a Tank-irrigated Landscape in South India." Development and Change 28(3):467-504.

Oldstone-Moore, Christopher. 2011. "Mustaches and Masculine Codes in Early Twentieth-Century America." Journal of Social History 45(1):47-60.

Pandian, Anand. 2008. "Cinema in the Countryside: Popular Tamil Film and the Remaking of Rural Life." Pp. 124-38 in Tamil Cinema: The Cultural Politics of India's Other Film Industry, edited by S. Velayutham. Abingdon: Routledge.

Pandian, Anand. 2015. Reel World: An Anthroplogy of Creation. Durham, NC: Duke University Press. 
Pandian, M. S. S. 1992. The Image Trap. New Delhi: Sage.

Pandian, M. S. S. 1996a. "Tamil Cultural Elites and Cinema: Outline of an Argument." Economic and Political Weekly 31(15):950-55.

Pandian, M.S.S. 1996b. "Politics of Representation." Pp. 533-49 in Region, Religion, Caste and Culture in Contemporary India, edited by T.V. Sathyamurthy. Delhi: Oxford University Press.

Pandian, M. S. S. 2000. “Dalit Assertion in Tamilnadu: An Explanatory Note.” Journal of Indian School of Political Economy 12(3 and 4):501-17.

Perinbanayagam, R. S. 1971. “Caste, Politics and Art.” The Drama Review 15(2):206-11.

Pinney, Christopher. 1995. "Hindi Cinema and Half-forgotten Dialects: An Interview with Ashis Nandy." Visual Anthropology Review 11(2):7-16.

Rajadurai, S. V and V. Geetha. 1996. "DMK Hegemony: The Cultural Limits to Political Consensus." Pp. 550-80 in Region, Religion, Caste, Gender and Culture in Contemporary India, edited by T. V. Sathyamurthy. Delhi: Oxford University Press.

Rajangam, Stalin. 2014. “Jallikattu: Power Play by Caste Bigwigs in Villages.” Times of India, May 12. Retrieved August 25, 2014 (http://timesofindia.indiatimes.com/city/chennai/JallikattuPower-play-by-caste-bigwigs-in-villages/articleshow/34999811.cms).

Rajangam, Stalin. 2008. Ariya Uthadum Unadu, Thiravida Uthadum Undadu (Both Aryan Lips and Dravidian Lips Are Yours: Essays on Tamil Cinema). Chennai: Thenthisai Publication.

Ravindran, Gopalan. 2008. "Malaysian Tamils and Transnational Tamil Cinema: Diasporic Identities, ‘Crisis Heterotopia' and 'Aura.”' Jurnal Skrin Malaysia 5:99-118.

Sevea, Iqbal . 2014. “'Kharaak Kita Oi!' Masculinity, Caste and Gender in Punjabi Films.” BioScope 5 (2):129-40.

Simon, Roger. 1989. “Gramsci: A Glossary of Revolution.” Marxism Today April, Gramsci Supplement:V.

Sivathamby, Karthigesu. 1971. "Politicians as Players." The Drama Review 15(2):212-20.

Sivathamby, Karthigesu. 1981. Tamil Film as a Medium of Political Communication. Madras: New Century Book House.

Sreenivasan Muktha. 1993. Tamil Thiraipada Varalaru (The History of Tamil Cinema). Madras: Gangai Puthaga Nilayam.

Srinivas, S.V. 2000. "Is There a Public in the Cinema Hall?" Framework: The Journal of Cinema and Media 42. Retrieved October 28, 2015 (https://www.academia.edu/558095/

Is_there_a_Public_in_the_Cinema_Hall).

Srinivas, K. Ravi and Sundar Kaali. 1998. "On Castes and Comedians: The Language of Power in Recent Tamil Cinema." Pp. 208-27 in The Secret Politics of our Desires: Innocence, Culpability and Indian Popular Cinema, edited by A. Nandy. Delhi: Oxford University Press.

Srivathsan, A. 2007. “Ethnography of Violence." The Hindu, April 29. Retrieved October 28, 2015 ( http://www.thehindu.com/todays-paper/tp-features/tp sundaymagazine/ethnography-ofviolence/article2275175.ece).

Subramanian, Narendra. 1999. Ethnicity and Populist Mobilization. Delhi: Oxford University Press.

Tamizhmurasu, V. 2008. Sivappu eadu (The Red Book). Madurai: Vanangamudi Pathippagam. 
Teltumbde, Anand. 2011. "Killing Pallars to Propitiate Thevars." Countercurrents, October 30. Retrieved August 4, 2016 (http://www.countercurrents.org/teltumbde301011.htm).

The Economic Times. 2016. "Dalits in Tamil Nadu Continue to Pay with Their Lives for Marrying Outside their Caste while Parties Look the other Way." The Economic Times, March 27. Retrieved March 31, 2016 (http://economictimes.indiatimes.com/news/politics-and-nation/dalits-in-tamilnadu-continue-to-pay-with-their-lives-for-marrying-outside-their-caste-while-parties-look-theother-way/articleshow/51565550.cms)

Thirumaavalavan, Thol. 2004. Talisman: Extreme Emotions of Dalit Liberation. Translated by M. Kandasamy. Kolkata: Samya.

Washbrook, David. 1976. The Emergence of Provincial Politics: The Madras Presidency 1870-1920. Cambridge: Cambridge University Press.

Washbrook, David. 1989. “Caste, Class and Dominance in Modern Tamil Nadu." Pp. 204-64 in Dominance and State Power in India. Vol. 1, edited by F. Frankel and M.S.A. Rao. Delhi: Oxford University Press.

\section{NOTES}

1. Reasons of space preclude an analysis of trends across India, but see Dwyer (2006) for a discussion of nationalism and religion in Indian cinema more broadly.

2. Though see Leonard (2015) for a recent exception.

3. Whilst this paper does not emerge directly from a particular research project, both authors have been engaged in long-standing research and writing on caste and politics in Tamil Nadu. Karthikeyan worked as a journalist for The Hindu newspaper before beginning a $\mathrm{PhD}$ and conducting qualitative fieldwork in 2014-15. Gorringe carried out ethnographic research on Dalit politics in 1998-9 and then again 2012, funded by the ESRC (Grant RES-062-23-3348). Where relevant, this research is drawn upon in our analysis.

4. In 1939 Muthuramalinga Thevar met Subhas Chandra Bose while attending a Congress Session. Bose later quit Congress and formed the Forward Bloc and Muthuramalinga Thevar, as an ardent supporter, became his lieutenant in the Madras Presidency. After the formation of the Forward Bloc, Bose visited Madurai in 1939. Thevar's association with Bose metonymically implies martial prowess, because he saw Gandhian non-violence as inimical to the interests of the Indian freedom struggle and formed the Indian National Army to fight the British (Srinivas and Kaali 2002).

5. This Act meant that a whole class of people considered to be martial tribes were depicted as habitual criminals and were subject to colonial subjugation. They were depicted as uncivilized within colonial administrative discourse and seen to require punitive measures to reform them. The Act was repealed when India gained Independence.

6. Sivappu Malli (Red Jasmine, Rama Narayanan, 1981) and Kann Sivanthaal Mann Sivakkum (When eyes turn red, the soil too will, Sreedhar Rajan, 1983) are classics of this genre-dealing with labour unrest, feudal landlords and class disputes. The occasional film since that point has addressed similar themes, including Aravindhan (A Name, T. Nagarajan, 1997) and Anbe Sivam (Love is God, C. Sundar, 2003) but these are few and far between.

7. As Pandian (2015:10) argues: "One of the most distinctive qualities of recent Tamil cinema is its concern for nativity, a word that the industry uses as a shorthand for everyday habits, customs, and spaces. Pursuit of the everyday has taken Tamil filmmakers far beyond the studio confines of Kodambakkam, into the shoreline quarters and slum alley-ways of Chennai and into countryside tracts far from that capital city." 
8. We are grateful to one of the reviewers for noting how Thevar appropriation of cinematic narratives resembles the construction of caste histories and myths of origin in earlier periods.

9. For a Thevar version of history (in Tamil) see here: http://thevarhistory.webs.com/

10. Watch the director's interview here https://www.youtube.com/watch?v=uFR0TbCFwuw

11. See the videos used in the Thevar History site here: http://thevarhistory.webs.com/. Songs glorifying Muthuramalinga Thevar are repeatedly played at Thevar caste events.

12. For an explicit recognition of the significance of the mustache see here: http:// minimalmovieposters.in/post/25296716677/thevar-magan-1992-by-ab-first-published-in

13. See and hear the song here: https://www.youtube.com/watch?v=uXZet9MqMkI

14. See the clip here: https://www.youtube.com/watch?v=CX-YwZvRNDc

15. See the song here: http://www.youtube.com/watch?v=PjuvfffWFak

16. The significance of such films in caste sentiment and mobilisation is seen in the Pallar magazine Paatali Muzhakkam (March 1997; Volume 1, Number 42) in which they discussed the need to counter Thevar portrayals with films of their own. They named the film company, established for this purpose, Devendra Thirai Pada Niruvanam (Devendra Film Company). The first production they mooted was to depict one of their leaders, Thekkampatti Balasundarasu, to be titled Anjanenjan Balasundararasu (Brave Heart Balasundarasu).

17. Caste clashes erupted in Ramnad district in 1957 between Thevars and Pallars. The clash had political undercurrents since the Thevars supported the All India Forward Bloc and Pallars backed the Indian National Congress. Following initial clashes in July, Immanuel Sekaran-who represented the Dalits at a peace meeting in Mudukulathur-was murdered in September. Dalits blamed Muthuramalinga Thevar and violent clashes led to the deaths of many people (Teltumbde 2011; Karthikeyan 2016).

18. It is worth noting here that, having experienced the uses and consequences of Thevar Magan, Dalit groups protested vigorously in response to the release of its sequel: http:// www.hindu.com/2003/05/17/stories/2003051703120500.htm. The association between the soundtrack to the film and caste violence was evident during Karthikeyan's fieldwork in 2014, when police authorities clamped down on the playing of such songs during Guru Pujas marking the birth of Thevar for fear of conflict.

19. See the Thevar Magan movie poster: http://www.behance.net/gallery/Minimalistic-poster-ofThevar-Magan/6866047; http://www.outlookindia.com/article.aspx?281019.

20. A version of the song may be heard here: https://www.youtube.com/watch?v=SkBoJsq4n1A

21. See the passage here: https://www.youtube.com/watch?v=8N3oJSwsKQY

22. Interviews in 2012 in Alanganallur-home of one of the most popular bull-taming eventsstressed that Dalit participation served to increase caste tensions in the area.

23. For more on this story see: http://articles.timesofindia.indiatimes.com/2012-06-21/ madurai/32351276_1_theatre-dalit-leader-gang

24. Dr Krishnasamy's interview is featured here: http://www.hindu.com/2003/05/17/ stories/2003051703120500.htm

25. See: http://www.rediff.com/movies/2003/may/16kamal.htm

26. For details see the story here: http://www.hindu.com/2003/06/19/ stories/2003061904940400.htm

27. See reports by the Madurai based NGO Evidence on Violence against Dalits and the rise in honor-based crimes: http://evidence.org.in/dalit.html. 


\section{ABSTRACTS}

Whilst much has been written about the significance of caste in Tamil politics, there has been less attention paid to the ways in which caste is played out in the cultural sphere. This is particularly surprising given the close links between cinema, caste and politics in the state. In this paper we offer an analysis of feature films produced since 1985 to suggest that representations of caste dominance have served to reinforce caste-based identities and a social common-sense which equates particular intermediate castes with dominance, valor, heroism and violence. Additionally we argue that there is a symbiotic relationship between caste politics and cinema particularly through the naturalization of intermediate caste markers and narratives.

INDEX

Keywords: Tamil cinema, caste, conflict, honor, identity

\section{AUTHORS}

\section{KARTHIKEYAN DAMODARAN}

PhD Candidate, Centre for South Asian Studies, University of Edinburgh

\section{HUGO GORRINGE}

Senior Lecturer in Sociology, University of Edinburgh 